\title{
Resveratrol Activated Sonic Hedgehog Signaling to Enhance Viability of NIH3T3 Cells in Vitro via Regulation of Sirt1
}

\author{
Shuang Guo Hongyan Liao Jie Liu Jing Liu Fanren Tang Zhongxiang He \\ Yangchun Li Qin Yang
}

Department of Neurology, The first Affiliated Hospital of Chongqing Medical University, Chongqing, China

\section{Key Words}

Resveratrol • NIH3T3 cells • Sonic hedgehog signaling • Primary cilia • SRT1720 • Sirtinol • Sirt1

\begin{abstract}
Background/Aims: Injuries of the brain and spinal cord result in the formation of glial (reactive gliosis) and fibrotic (formed by fibroblasts) scars. Recent studies have shown that the fibrotic scar was much more important for hindering regeneration after brain or spinal cord injury than the astrocytic scar. However, it has been given much less attention for effects and mechanism of fibroblasts during formation of the fibrotic scar. Resveratrol may be a potential antiscarring agent in burn-related scarring and keloid fibroblasts. However, it is unclear whether and how resveratrol affects formation of the fibrotic scar after brain or spinal cord injury. Earlier studies have shown that the activated Shh signaling has anti-apoptosis, anti-oxidation, anti-inflammation properties. Moreover, resveratrol can activate the Shh signaling. However, it is unclear how resveratrol activates the Shh signaling. Resveratrol is a activator of Sirt1. It is unknown whether resveratrol activates the Shh signaling via Sirt1. Methods: NIH3T3 cells, a fibroblast cell line, were used as model cells and treated with drugs. Cell viability was assessed by Cell Counting Kit 8 . The expressions and activity of Shh signaling pathway proteins were evaluated by immunocytochemistry and Western blotting. Transcriptional activity of Gli- 1 was detected with Dual-Luciferase Reporter Gene Assay Kit. Results: Resveratrol, Sirt1 agonist STR1720 and recombinant mouse Shh protein, an activator of hedgehog signaling, enhanced the viability of NIH3T3 cells, promoted Smo to translocated to the primary cilia and Gli-1 entered into the nuclei from cytoplasm, and upregulated expressions of Shh, Ptc-1, Smo, and Gli-1 proteins, which can be reversed by Smo antagonist cyclopamine and Sirt1 antagonist Sirtinol. Additionally, resveratrol increased transcriptional activity of Gli-1. Conclusion: We indicate in the first time that it may be mediated by Sirt1 for resveratrol activating the Shh signaling to enhance viability of NIH3T3 cells, and Sirt1 may be a regulator for upstream of
\end{abstract}

\begin{tabular}{ll}
\hline Qin Yang & Department of Neurology, the 1st Affiliated Hospital of Chongqing Med.Univ. \\
& 1 Youyi Road, Yuzhong District, 400016, Chongqing (China) \\
& Tel. 86-23-89012008, E-Mail xyqh200@126.com
\end{tabular}




\section{Cellular Physiology Cell Physiol Biochem 2018;50:1346-1360

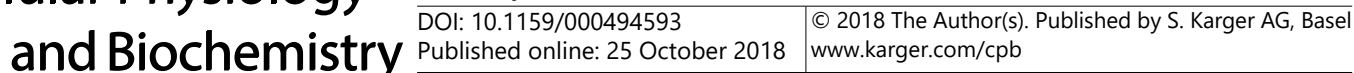 \\ Guo et al.: Resveratrol Activated Sonic Hedgehog Signaling to Enhance Viability of}

NIH3T3 Cells via Sirt1

the Shh signaling pathway.This study provides a basis for further investigating effects and mechanism of resveratrol during the formation of fibrous scar after brain or spinal cord injury.

(C) 2018 The Author(s)

Published by S. Karger AG, Basel

\section{Introduction}

Traumatic, ischemical or autoimmune injuries of the brain and spinal cord result in the formation of a permanent scar, which can be categorized into "glial" and "fibrotic" scars $[1,2]$. The glial scar is generally referred to reactive gliosis region that surrounds the central core and prevents non-central nervous system (CNS) cells (such as leukocytes) from invading the CNS parenchyma. The glial scar has been intensely studied for its role in inhibition of axon regeneration, reconstitution of the $\mathrm{BBB}$, prevention of neuronal degeneration and so on $[3,4]$. However, much less is known about the fibrotic scar formed by fibroblasts, which have invaded the lesion core from adjacent meningeal and perivascular cells. Recent studies have shown that the fibrotic scar was much more important for hindering regeneration after brain injury than the astrocytic scar [5-7]. However, it has been given much less attention for effects and mechanism of fibroblasts during formation of the fibrotic scar.

Resveratrol is a naturally occurring polyphenolic phytoalexin which is generally present in semen cassiae, peanuts, grapes, red wine, polygonum cuspidatum and mulberries [8]. Growthing studies have shown that resveratrol has anti-cancer, anti-aging, anti-inflammatory, anti-atherosclerosis, anti-oxidation, scavenging free radicals and neuroprotective properties [9-23]. Moreover, resveratrol may be a potential anti-scarring agent in burn-related scarring and keloid fibroblasts $[24,25]$. However, it is not clear whether and how resveratrol affects formation of the fibrotic scar after injuries of the brain and spinal cord.

Sonic hedgehog (Shh) ligand, Patched (Ptc) and Smoothened (Smo) receptors, and gliomaassociated oncogene homolog transcription factors (Gli-1, -2 and -3) are principle members of the canonical Shh signaling pathway. When Shh binds to the Ptc receptor at the cell surface, Smo migrates to the primary cilia from the cytoplasm, and activate Gli transcription factors and downstream effectors of the Shh pathway [26-28]. Shh signaling plays a key role during embryogenesis, organic formation, proliferation and differentiation of cells or stem cells. In the pathological condition such as stroke, trauma and infection, or stimulation of other methods such as drugs, cells and rehabilitation, the Shh signaling could be activated. The activated Shh signaling can enhance viability, proliferation or differentiation of cells or stem cells, reduce damage and promote functional recovery via anti-apoptosis, anti-oxidation, anti-inflammation, and so on [29-32]. Moreover, more studies have shown that resveratrol can activate the Shh signaling $[19,21,22,32]$. However, it is currently unknown for the role of the Shh signaling in the formation of fibrotic scars after brain injury. It is also unclear how resveratrol activates the Shh signaling.

Given that resveratrol is a activator of nicotinamide adenine dinucleotide-dependent protein deacetylase Sirtuin l (Sirt1). Activated Sirt1 by resveratrol has anti-aging, neuroprotective and neurogenetic and anti-hypertrophic scar effects [33-39]. Tiberi et al. reported that BCL6/BCOR/SIRT1 complex inhibited medulloblastoma and enhanced neurogenesis by suppressing the Shh signaling [40]. Tang et al. reported that Sirtinol, a Sirt1 inhibitor, inhibited expressions of Shh, Ptc-1, Smo, and Gli-1 proteins [21]. Therefore, we speculate that resveratrol may activate the Shh signaling via Sirt1 and Sirt1 may be a regulator for upstream of the Shh signaling pathway.

NIH3T3 cell is a fibroblast cell line. Its cultured technology is relatively mature and its growth rhythm in vitro has a more comprehensive understanding. NIH3T3 cells in vitro can maintain good divisive, proliferative and generative capacity. In the research of basic and clinical medicine, it has been widely used to study cellular aging, drug action and mechanism. Especially, NIH3T3 cells are generally selected for knockout or reintroduction of gene. In addition, in peripheral organs, recent genetic fate mapping studies showed that resident and circulating fibroblasts are the key effector cells in tissue remodeling and fibrosis [41, 42]. In 


\section{Cellular Physiology Cell Physiol Biochem 2018;50:1346-1360 \\ \begin{tabular}{ll|l} 
and Biochemistry Published online: 25 October 2018 & $\begin{array}{l}\odot 2018 \text { The Author(s). Published by S. Karger AG, Basel } \\
\text { www.karger.com/cpb }\end{array}$ \\
\hline
\end{tabular}}

Guo et al.: Resveratrol Activated Sonic Hedgehog Signaling to Enhance Viability of

NIH3T3 Cells via Sirt1

the CNS, meningeal and peirvascular fibroblasts play an important role in formation of the fibrotic scar after brain injury [5-7].

Therefore, in the present study, NIH3T3 cells were used as model cells to illuminate whether resveratrol affects viability of fibroblasts in physiological condition, activates the Shh signaling via Sirt1, and Sirt1 is a regulator for upstream of the Shh signaling pathway. We definitively found that resveratrol, Sirt1 agonist SRT1720 and Shh protein, an activator of hedgehog signaling, enhanced viability of NIH3T3 cells and activated the Shh signaling. Shh antagonist cyclopamine and Sirt1 antagonist Sirtinol decreased viability of NIH3T3 cells and inhibited the Shh signaling. In other words, resveratrol activates the Shh signaling to enhance viability of NIH3T3 cells via Sirt1 and Sirt1 may be a regulator for upstream of the Shh signaling pathway. This study provides a basis for further investigating effects and mechanism of resveratrol during the formation of fibrous scar after cerebral ischemic injury.

\section{Materials and Methods}

\section{Culture of NIH3T3 cells and Drug treatment}

NIH3T3 cells (Shanghai Xin Yu Biological Technology Co., Ltd.Shanghai,China) were cultured with complete medium composed of DMEM/F12 (Gibco, USA), 10\% FBS (PAN,South America), $100 \mathrm{U} / \mathrm{ml}$ penicillin, and $100 \mathrm{mg} / \mathrm{ml}$ streptomycin, and maintained at $37^{\circ} \mathrm{C}$ in a humidified atmosphere containing $5 \%$ $\mathrm{CO}_{2}$. When the cells reached $80 \%$ confluence, they were digested with $0.125 \%$ trypsin and subcultured 1:3.

To investigate whether resveratrol enhances NIH3T3 cells viability after starvation for $24 \mathrm{~h}$, three groups were studied: 1) control (Ctrl) group. NIH3T3 cells were treated with complete medium containing ethanol (volume fraction 1.3\%) for $24 \mathrm{~h} ; 2$ ) resveratrol group. NIH3T3 cells were maintained in complete medium containing different concentrations $(0.1,0.5,1,5,10,20,40$ and $80 \mathrm{umol} / \mathrm{L}$ ) resveratrol (purity $99 \%$,Sigma,USA) for $24 \mathrm{~h}$. 3) blank group. There was only complete medium and no NIH3T3 cells.The best effect was observed with a concentration of $1 \mu \mathrm{mol} / \mathrm{L}$ resveratrol, and thus $1 \mu \mathrm{mol} / \mathrm{L}$ resveratrol was used for further study.

To determine whether the Shh signaling pathway plays a role in the effect of resveratrol on viability of NIH3T3 cells, five groups were studied: 1) control (Ctrl) group. NIH3T3 cells were treated with complete medium containing ethanol (volume fraction 1.3\%) for $24 \mathrm{~h}$; 2) $1 \mu \mathrm{mol} / \mathrm{L}$ resveratrol (Res1) group. NIH3T3 cells were maintained in complete medium containing $1 \mu \mathrm{mol} / \mathrm{L}$ resveratrol for $24 \mathrm{~h}$; 3) $5 \mu \mathrm{mol} / \mathrm{L}$ cyclopamine (Cyc) group, a Smo inhibitor. NIH3T3 cells were maintained in complete medium containing 5 $\mu \mathrm{mol} / \mathrm{L}$ cyclopamine (purity 98\%, Cayman, USA) for $24 \mathrm{~h} \mathrm{4)} 1 \mu \mathrm{mol} / \mathrm{L}$ resveratrol+ $5 \mu \mathrm{mol} / \mathrm{L}$ cyclopamine (Res1+Cyc) group. NIH3T3 cells were maintained in complete medium containing $1 \mu \mathrm{mol} / \mathrm{L}$ resveratrol and $5 \mu \mathrm{mol} / \mathrm{L}$ cyclopamine for $24 \mathrm{~h}$. 5) blank group. There was only complete medium and no NIH3T3 cells.

To examine whether Sirt1 is associated with Shh signaling, NIH3T3 cells were divided into six groups: 1) control (Ctrl) group.Cells were treated with complete medium containing ethanol (volume fraction 1.3\%) for $24 \mathrm{~h}$;2) $1 \mu \mathrm{mol} / \mathrm{L}$ resveratrol (Res1) group.Cells were maintained in complete medium containing 1 $\mu \mathrm{mol} / \mathrm{L}$ resveratrol for $24 \mathrm{~h}$; 3) $0.4 \mu \mathrm{mol} / \mathrm{L}$ SRT1720 (SRT ) group, a Sirt1 agonist. Cells were maintained in complete medium containing $0.4 \mu \mathrm{mol} / \mathrm{L}$ SRT1720 (purity 98\%, BioVision,USA) for $24 \mathrm{~h}$; 4$) 10 \mu \mathrm{mol} / \mathrm{L}$ sirtinol (Sirtinol) group, a Sirt1 antagonist. Cells were maintained in complete medium containing 10 $\mu \mathrm{mol} / \mathrm{L}$ sirtinol (purity 98\%, Ann Arbor,USA) for $24 \mathrm{~h}$; 5) $50 \mathrm{ng} / \mathrm{mL}$ recombinant mouse sonic hedgehog (Shh) , Cells were maintained in complete medium containing $50 \mathrm{ng} / \mathrm{mL}$ Shh (purity 97\%, ProSpec,USA) for 24 h. 6) blank group. There was only complete medium and no NIH3T3 cells.

\section{CCK-8 Assay for Cell viability}

The viability of cells was assessed with CCK-8 assay (Kumamoto, Japan). Briefly, NIH3T3 cells (approximately 2000/well) were seeded in poly-L-Lysine-coated 96-well plates with six replicates per group, and subjected to the various treatments described previously. CCK-8 solution $(10 \mathrm{uL} / 100 \mathrm{uL})$ was added to each culture well, and cells were incubated for $4 \mathrm{~h}$ at $37^{\circ} \mathrm{C}$. Absorbance at $450 \mathrm{~nm}$ was measured with a microplate reader (Thermo Labsystems, Vantaa, Finland). Each experiment was repeated for three times. 


\section{Cellular Physiology Cell Physiol Biochem 2018;50:1346-1360 \begin{tabular}{ll|l} 
DOl: 10.1159/000494593 & $\begin{array}{l}\text { O 2018 The Author(s). Published by S. Karger AG, Basel } \\
\text { www.karger.com/cpb }\end{array}$ \\
\cline { 2 - 4 }
\end{tabular}}

Guo et al.: Resveratrol Activated Sonic Hedgehog Signaling to Enhance Viability of

NIH3T3 Cells via Sirt1

\section{Immunocytochemistry}

Cells were seeded on coverslips coated with poly-L-lysine for three replicates in each group and fixed with $4 \%$ paraformaldehyde for $30 \mathrm{~min}$ at room temperature, then washed three times with PBS and permeabilized with $0.1 \%$ Triton X-100 for $30 \mathrm{~min}$ at room temperature. After three washes with PBS, cells were blocked with $10 \%$ normal goat serum for $30 \mathrm{~min}$ at $37{ }^{\circ} \mathrm{C}$, then incubated overnight at $4{ }^{\circ} \mathrm{C}$ with the following primary antibodies: monoclonal mouse anti-acetylated tubulin (anti-Ac-Tu) antibody (1:200, Sigma, USA), polyclonal rabbit anti-Gli-1 antibody (1:100, Abcam, UK), and rabbit anti-Smo antibody (1:200, Abcam,UK). After washed with PBS, cells were incubated with Alexa fluor 488 goat anti-rabbit or Alexa fluor 594 goat anti-mouse IgG (1:100, Beijing Zhongshan Golden Bridge, China) for $1 \mathrm{~h}$ at $37{ }^{\circ} \mathrm{C}$. The primary antibodies were replaced with PBS in the negative controls. Nuclei were counterstained with 4, 6-diamidino-2-phenylindole (DAPI, Beyotime, China ) for $5 \mathrm{~min}$ in the dark. Finally, cells were examined with laser confocal microscope (Nikon, Tokyo, Japan). Each experiment was repeated three times.

\section{Western blot analysis}

To analyse protein levels, cells were rinsed twice with ice-cold PBS, lysed in RIPA lysis buffer containing $1 \%$ PMSF (Beyotime Institute of Biotechnology), and incubated on ice for $30 \mathrm{~min}$. The protein was collected by centrifugation $(12,000 \mathrm{rpm}, 15 \mathrm{~min})$ at $4^{\circ} \mathrm{C}$, and protein concentration was quantified by BCA assay (Beyotime Institute of Biotechnology). Protein samples were mixed with $5 \times$ loading buffer $(1: 4)$ and boiled for $10 \mathrm{~min}$. Then, equal protein quantity for every control and test sample (50 $\mathrm{\mu} \mathrm{g}$ protein per lane) was separated by $10 \%$ sodium dodecyl sulfate-polyacrylamide gel electrophoresis, and transferred onto a polyvinylidene difluoride membrane (Millipore, Billerica, MA, USA). The membranes were blocked with $5 \%$ non-fat milk in PBS containing Tween 20 (2:1; PBST) for $2 \mathrm{~h}$ at room temperature and incubated overnight at $4^{\circ} \mathrm{C}$ with the following primary antibodies diluted in 5\% non-fat milk in PBST: polyclonal rabbit anti-Shh, anti-Ptch-1, anti-Smo, and anti-Gli-1 antibodies (1:100, respectively, both from Abcam, UK)); and rabbit anti-GAPDH antibody (1:1000, Beyotime, China) as an internal control. The membranes were washed three times with PBST on the second day, and subsequent incubation with peroxidase-conjugated affiniPure goat anti-rabbit IgG at $37^{\circ} \mathrm{C}$ for $1 \mathrm{~h}$. Immunoreactive bands were soaked with enhanced chemiluminescence and their intensities were semi-quantified in Quantity One software (Bio-Rad, Hercules, CA, USA). The gray ratio of the target protein to GAPDH protein represented the target protein relative expression level. Each experiment was repeated three times.

\section{Transfection and Luciferase assays}

To measure effect of resveratrol on the activation of Gli transcription, a reporter Adenovirus (Hanbio Biotechnology Co., Ltd. China) with multiple copies of the Gli recognition element and a minimal promoter upstream of the firefly luciferase gene was used. After NIH3T3 cells in 24-well plate were contransfected with $0.125 \mathrm{ul} \mathrm{Ad-Gli1-REminiCMV-luc} \mathrm{and} 0.125$ ul Renilla luciferase control reporter (Hanbio Biotechnology Co., Ltd. China) for 4-8h , medium containing virus was replaced by complete medium. At $24 \mathrm{~h}$, cells were administrated different concentration of resveratrol $(0.1,0.5,1,5,10,20,40$ and $80 \mathrm{umol} / \mathrm{L})$ and recombinant mouse Shh protein $(50 \mathrm{ng} / \mathrm{mL})$, and cultured for $8 \mathrm{~h}$. Then, cell lysate was collected and analyzed firefly luciferase and Renilla luciferase activities with Dual-Luciferase Reporter Gene Assay Kit (Beyotime, China). The increase of firefly luciferase activity was normalized to Renilla luciferase activity. Each experiment was repeated three times.

\section{Statistical analysis}

Quantitative data were presented as mean \pm standard deviation. One-way ANOVA were used to evaluate differences between groups. All data were analyzed with SPSS v.20.0 for Windows. A value of $P<0.05$ was defined as significant. 


\section{Results}

Concentration effects of resveratrol on viability of NIH3T3 cells

The optimal concentration effect of resveratrol on viability of NIH3T3 cells in vitro was evaluated with the CCK-8 assay. Various concentrations of resveratrol $(0.1 \mu \mathrm{mol} / \mathrm{L}, 0.5 \mu \mathrm{mol} / \mathrm{L}$, $1 \mu \mathrm{mol} / \mathrm{L}, 5 \mu \mathrm{mol} / \mathrm{L}, 10 \mu \mathrm{mol} / \mathrm{L}, 20 \mu \mathrm{mol} / \mathrm{L}, 40 \mu \mathrm{mol} / \mathrm{L}, 80 \mu \mathrm{mol} / \mathrm{L}$ ) were examined. As shown in Fig. 1A, viability of NIH3T3 cells was significantly increased in the $0.1,0.5$, and $1 \mu \mathrm{mol} / \mathrm{L}$ resveratrol $(0.602 \pm 0.065,0.679 \pm 0.047,0.774 \pm 0.054$, respectively) groups compared with the control $(0.585 \pm 0.039)$ group, and the highest viability was in the $1 \mu \mathrm{mol} / \mathrm{L}$ resveratrol group. On the contrary, viability of NIH3T3 cells was significantly decreased in the 5,10 , 20,40 and $80 \mu \mathrm{mol} / \mathrm{L}$ resveratrol $(0.556 \pm 0.041,0.428 \pm 0.043,0.395 \pm 0.031,0.373 \pm 0.017$, $0.361 \pm 0.016$, respectively) groups compared with the control group. These results show that low concentration resveratrol can enhance viability of NIH3T3 cells and high concentration resveratrol can attenuate viability of NIH3T3 cells. Therefore, concentrations of $1 \mu \mathrm{mol} / \mathrm{L}$ were selected for further study.

Shh signaling mediates resveratrol to increase viability of NIHT3 cells

In the present study, we used cyclopamine, a Smo receptor inhibitor, to study the role of the Shh signaling in resveratrol-enhancing viability of NIHT3 cells in vitro.

First, effects of resveratrol and cyclopamine on viability of NIH3T3 cells in vitro were evaluated with the CCK-8 assay. Compared with the control group $(0.563 \pm 0.034)$, the viability of cells in the resveratrol group $(0.778 \pm 0.371)$ was significantly increased. However, the effect of resveratrol on NIH3T3 cells viability was significantly reversed when cells were cultured with cyclopamine $(5 \mu \mathrm{mol} / \mathrm{L})(0.439 \pm 0.259)$ alone or with cyclopamine combined with resveratrol $(0.602 \pm 0.179)$. Furthermore, the minimum was in the cyclopamine alone group (Fig. 1B). These results demonstrate that blocking Shh signaling with cyclopamine cancels effects of resveratrol-enhancing cell viability.

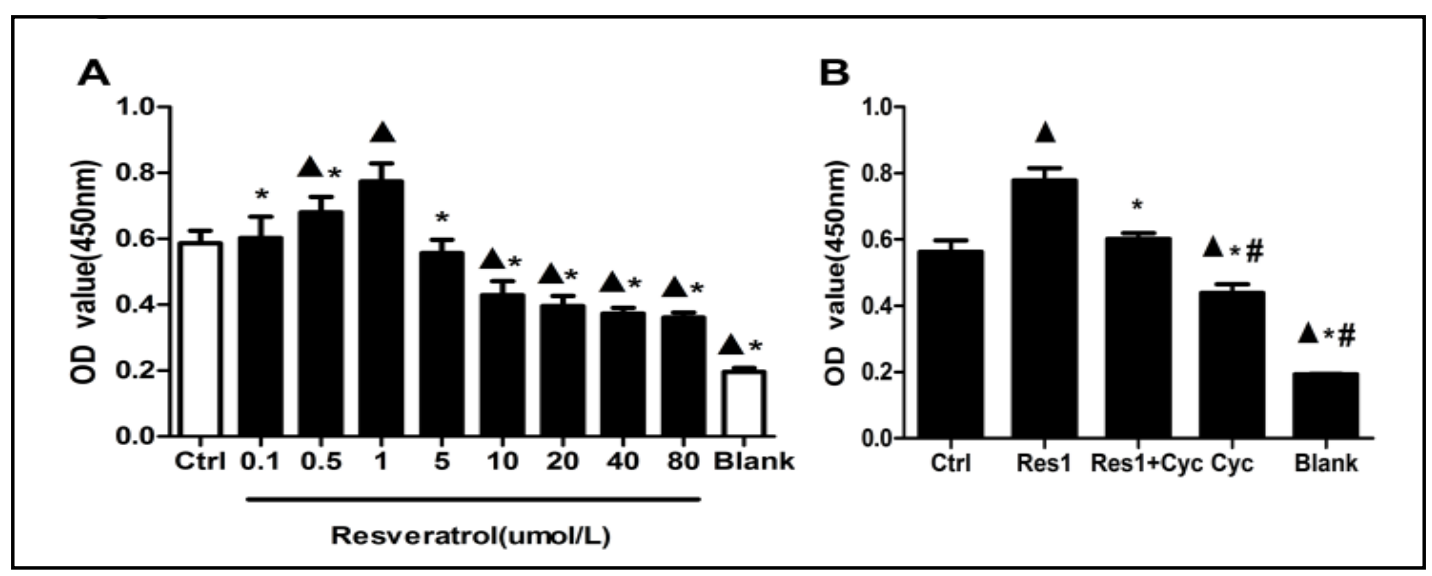

Fig. 1. Effects of resveratrol on NIH3T3 cells viability in vitro. (A) Concentration effects of resveratrol on NIH3T3 cells viability in vitro. Viability of NIH3T3 cells was significantly increased in the $0.1,0.5$, and 1 $\mu \mathrm{mol} / \mathrm{L}$ resveratrol groups compared with the control group, and the highest viability was in the $1 \mu \mathrm{mol} / \mathrm{L}$ resveratrol group. On the contrary, it was significantly decreased in the 5, 10, 20, 40 and $80 \mu \mathrm{mol} / \mathrm{L}$ resveratrol groups compared with the control group. ${ }^{\wedge} \mathrm{P}<0.05$ vs. Ctrl; ${ }^{*} \mathrm{P}<0.05$ vs Res1. (B) Cyclopamine cancels the effects of resveratrol on NIH3T3 cells viability. Resveratrol was significantly increased the viability of cells compared with the control group. However, the effect of resveratrol on NIH3T3 cells viability was significantly reversed when cells were cultured with cyclopamine alone or with cyclopamine combined with resveratrol. Moreover, the minimum was in the cyclopamine alone group. ${ }^{\Delta} \mathrm{P}<0.05$ vs. Ctrl; ${ }^{*} \mathrm{P}<0.05$ vs. Res 1 ; ${ }^{\mathrm{P}}<0.05$ vs. Res $1+$ Cyc (ANOVA, $\mathrm{n}=3$ each group).

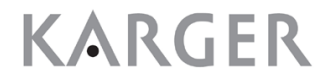



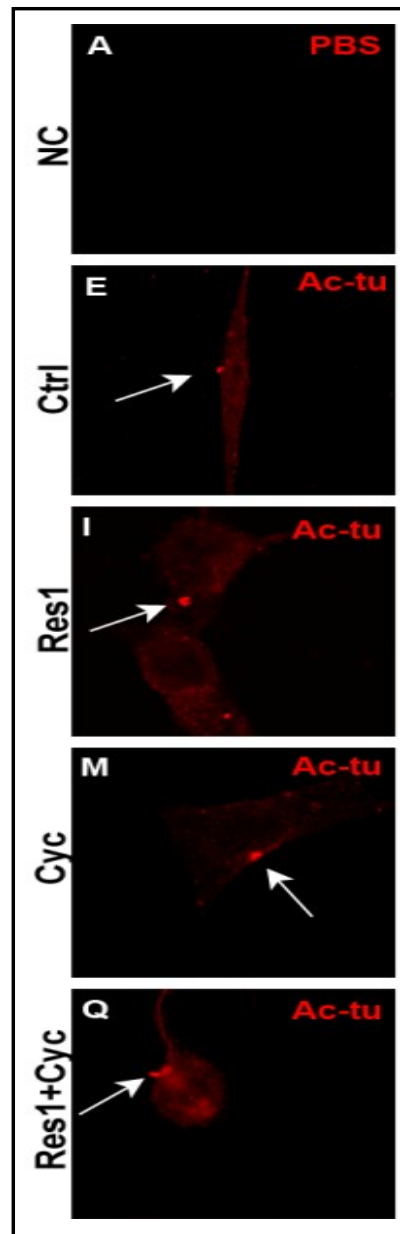
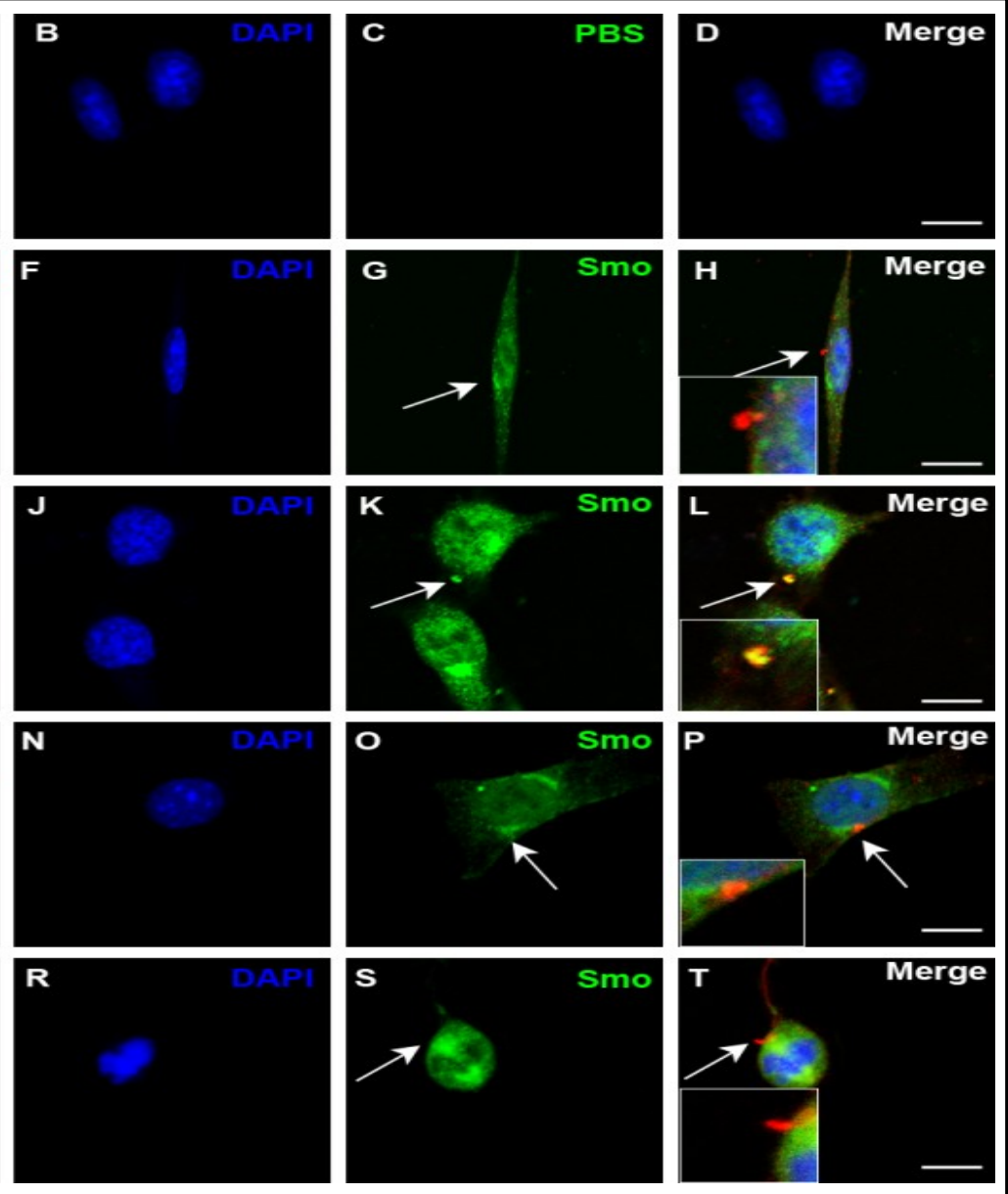

Fig. 2. Cyclopamine cancels the effects of resveratrol-promoting Smo to translocate into primary cilia from cytoplasm. Cells were immunostained with antibodies to Ac-tu (E, I, M, Q, red) and Smo (G, K, O, S, green). Nuclei were labeled with DAPI (B, F, J, N, R, blue). (A, C) The Ac-tu and Smo antibodies were replaced with PBS to serve as a negative control (NC). (D, H, L, P, T) Merges of A/B/C, E/F/G, I/J/K, M/N/O and Q/R/S. In the Ctrl, Cyc and Res1+Cyc groups, Smo lies in cytoplasm. In the Res1 group, Smo translocates into the primary cilia. Scale bars $=20 \mu \mathrm{m}$.

Next, we investigated whether resveratrol activated the Shh signaling in NIH3T3 cells. The canonical Shh signaling transduction in vertebrates needs the primary cilia. Acetylated a-tubulin (Ac-tu) is a marker of primary cilia. Immunofluorescence assay showed that NIH3T3 cells have a primary cilium (Fig. 2E, I, M, Q). In the control group, Smo lied in cytoplasm (Fig. $2 \mathrm{G}, \mathrm{H}$ ). In the resveratrol group, Smo translocated into the primary cilia (Fig. 2K, L). When NIH3T3 cells were cultured by cyclopamine alone or cyclopamine combined with resveratrol, Smo still deposited in cytoplasm (Fig. 2 O, P, S, T). These results indicate that cyclopamine inhibits effects of resveratrol-promoting Smo to translocate into the primary cilia.

Further, immunofluorescence assay showed that Gli-1 in the control group accumulated in cytoplasm (Fig. 3B, L). In the resveratrol group, Gli-1 almost transferred to the nuclei from the cytoplasm (Fig. 3C, M). At the same time, transcriptional activity of Gli-1, detected with Dual-Luciferase Reporter Gene Assay Kit, increased significantly in Shh and different concentration resveratrol groups, and the highest is $1 \mu \mathrm{mol} / \mathrm{L}$ resveratrol group which rose up to 8- to 9-fold (Fig. 3P). Moreover, Western blotting showed that expression of Gli1 protein in nuclei, Shh, Ptc- 1 and Smo protein in cytoplasm significantly increased in the resveratrol group than those in the control group (Fig. 3Q-U). However, when cells were treated with cyclopamine alone or cyclopamine combined with resveratrol, the effects of

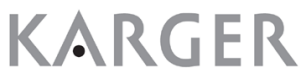




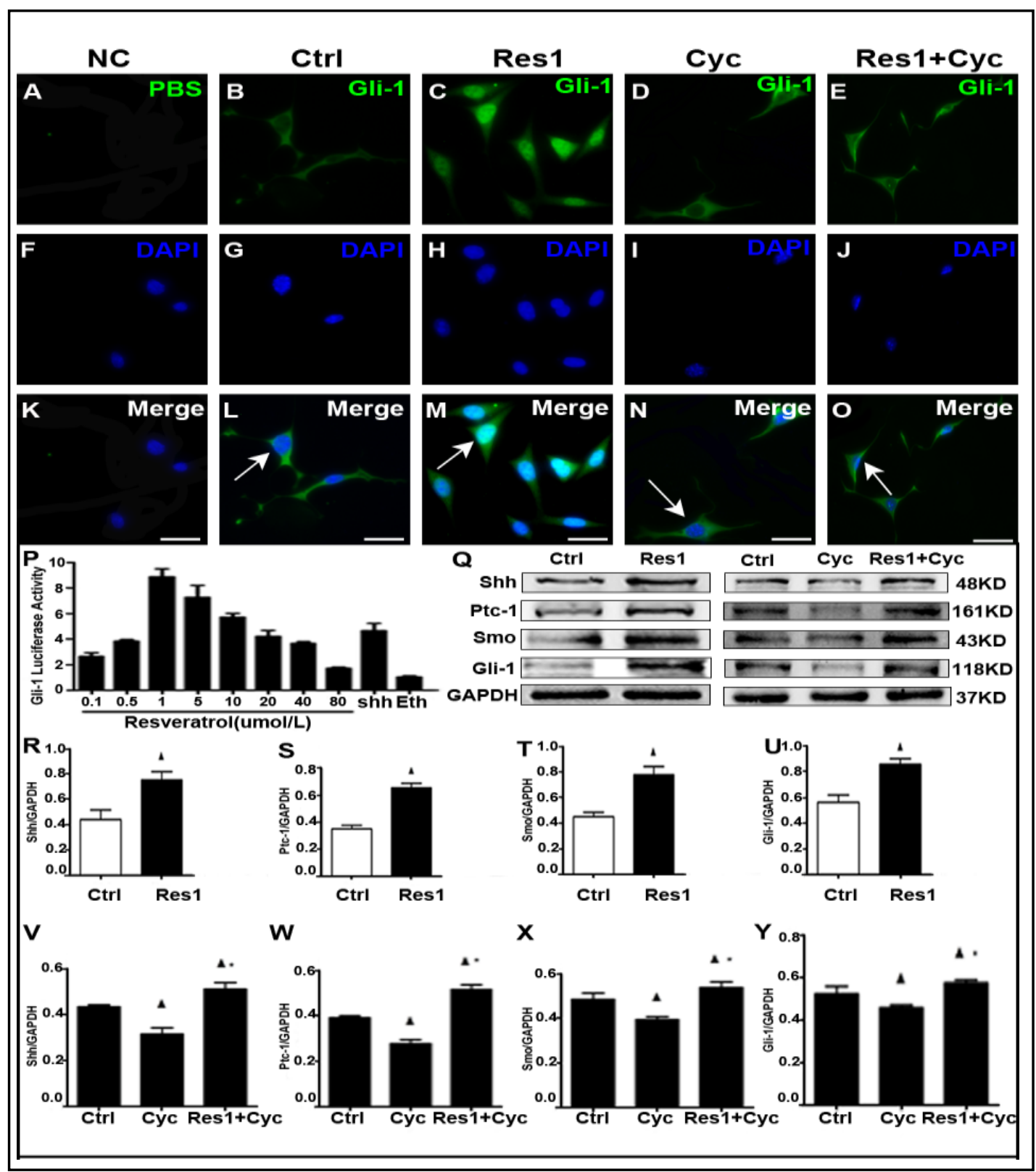

Fig. 3. Cyclopamine cancels resveratrol-triggering nuclear translocation of Gli-1 and up-regulating Shh, Ptc1, Smo, and Gli-1 expression in NIH3T3 cells. (A) Gli-1 antibody was replaced with PBS to serve as a negative control (NC). (B-E) Cells were immunostained with antibodies to Gli-1 (green). Nuclei were labeled with DAPI (F-J, blue). (K-O) Merges of A/F, B/G, C/H, D/I and E/J. In the Ctrl group, Gli-1 accumulated in cytoplasm (B, L). In the Res1 group, Gli-1 almost transferred to the nucleus (C, M). However, cyclopamine alone (D, N, Cyc) or cyclopamine combined with resveratrol (E, O, Res1+Cyc) inhibited the nuclear translocation of Gli1. (P) Transcriptional activity of Gli-1, detected with Dual-Luciferase Reporter Gene Assay Kit, increased significantly in Shh and different concentration resveratrol groups, and the highest is $1 \mu \mathrm{mol} / \mathrm{L}$ resveratrol group which rose up to 8- to 9-fold. (Q-Y) Cyclopamine inhibits effects of resveratrol-upregulating expression of Gli-1, Shh, Ptc-1 and Smo proteins with Western blotting assay. These results indicate that resveratrol activates the Shh signaling. ${ }^{\wedge} \mathrm{P}<0.05$ vs. Ctrl; ${ }^{*} \mathrm{P}<0.05$ vs. Cyc (ANOVA, $\mathrm{n}=3$ each group). Scale bars $=60 \mu \mathrm{m}$. 
Guo et al.: Resveratrol Activated Sonic Hedgehog Signaling to Enhance Viability of

NIH3T3 Cells via Sirt1

Fig. 4. Effects of resveratrol, SRT1720, Sirtinol and Shh on NIH3T3 cells viability in vitro. Resveratrol (Res1), SRT1720 (SRT) and Shh significantly increased viability of the NIH3T3 cells than those in the control group in vitro. Sirtinol significantly decreased viability of the NIH3T3 cells than those in the control group. ${ }^{\Delta} \mathrm{P}<0.05$ vs. Ctrl; ${ }^{*} \mathrm{P}<0.05$ vs. Res $1 ;{ }^{\#} \mathrm{P}<0.05$ vs. SRT; ${ }^{\circ} \mathrm{P}<0.05$ vs. Sirtinol (ANOVA, $n=3$ each group).
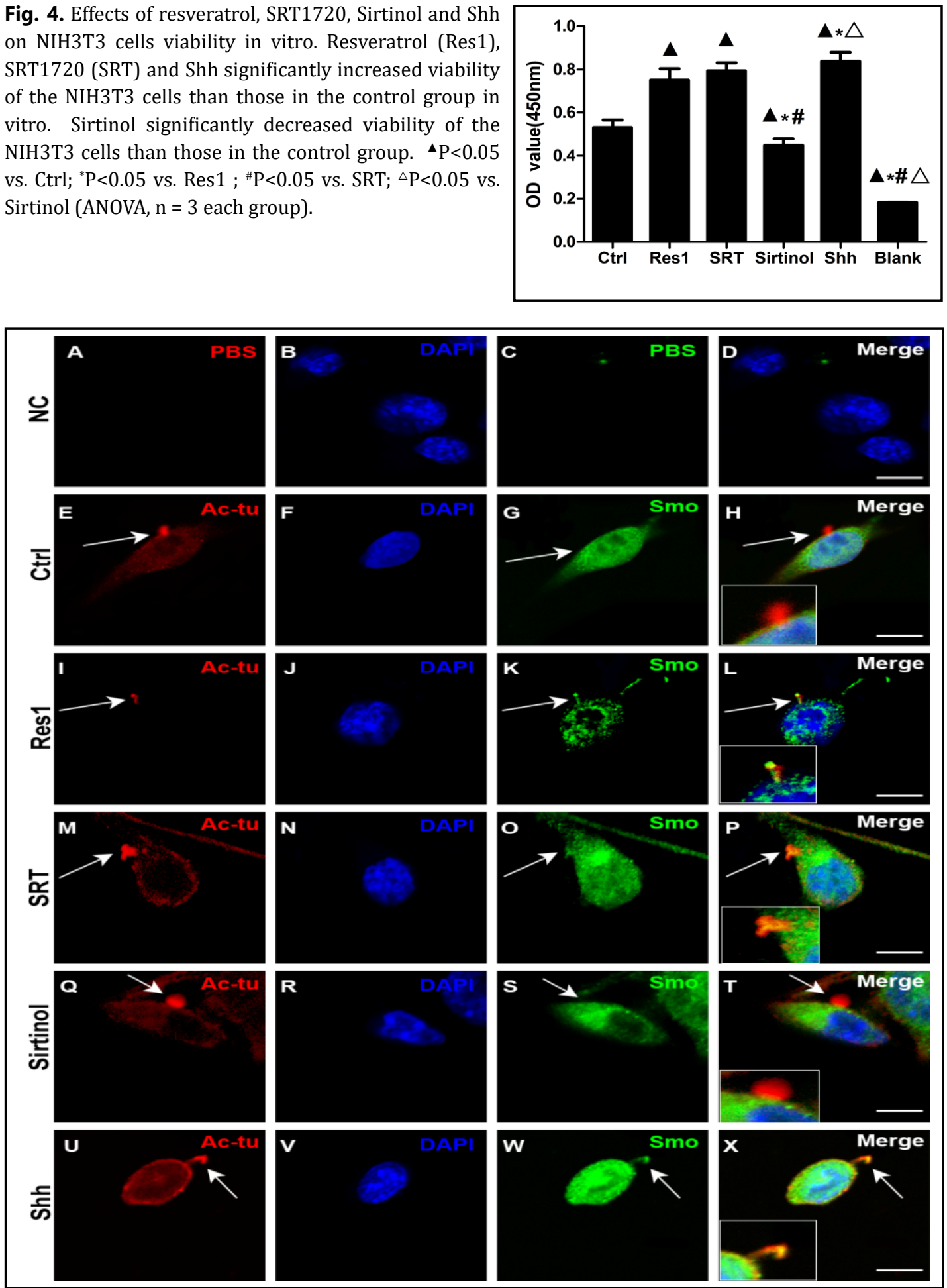

Fig. 5. Effects of resveratrol (Res1), SRT1720 (SRT), Sirtinol and Shh on Smo- translocating into primary cilia from cytoplasm in the NIH3T3 cells in vitro. Cells were immunostained with antibodies to Ac-tu (E, I, M, Q, U, red) and Smo (Q, K, O, S, W, green). Nuclei were labeled with DAPI (B, F, J, N, R, V, blue). (A, C) The Ac-tu and Smo antibodies were replaced with PBS to serve as a negative control (NC). (D, H, L, P, T, X) Merges of A/B/C, E/F/G, I/J/K, M/N/O, Q/R/S and U/V/W. In the Ctrl and Sirtinol group, Smo lies in cytoplasm. In the Res1, SRT and Shh groups, Smo translocates into the primary cilia. Scale bars $=20 \mu \mathrm{m}$. 


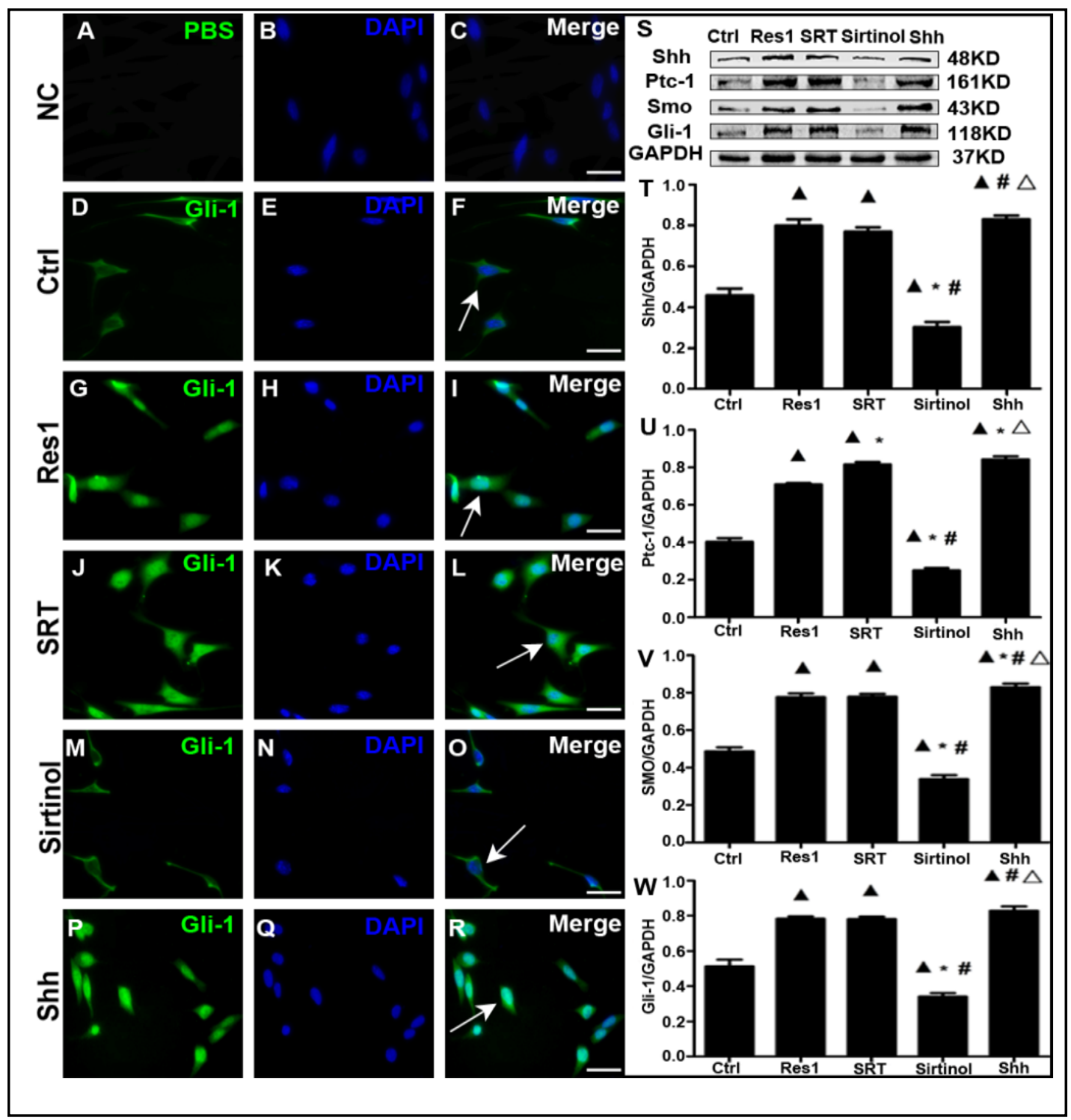

Fig. 6. Effects of resveratrol (Res1), SRT1720 (SRT), Sirtinol and Shh on nuclear translocation of Gli-1 and expression of Shh, Ptc-1, Smo, and Gli-1 proteins in NIH3T3 cells. (A) Gli-1 antibody was replaced with PBS to serve as a negative control (NC). (D, G, J, M, P) Cells are immunostained with antibodies to Gli-1 (green). Nuclei were labeled with DAPI (B, E; H, N, K, Q blue). (C, F, I, L, O, R) Merges of A/B, D/E, G/H, J/K, M/N and P/Q. In the Ctrl and Sirtinol group, Gli-1 accumulated in cytoplasm (D and F, M and O). In the Res1, SRT and Shh groups, Gli-1 almost transferred to the nucleus (G and I, J and L, P and R). (S-wW) Effects of resveratrol, SRT1720, Sirtinol and Shh on expression of Gli-1, Shh, Ptc-1 and Smo protein with Western blotting assay. These results indicate that resveratrol, SRT1720 and Shh activate and Sirtinol inhibits the Shh signaling. ${ }^{\wedge} \mathrm{P}<0.05$ vs. Ctrl; ${ }^{*} \mathrm{P}<0.05$ vs Res $1 ;{ }^{*} \mathrm{P}<0.05$ vs. SRT; ${ }^{\triangle} \mathrm{P}<0.05$ vs. Sirtinol (ANOVA, $\mathrm{n}=3$ each group). Scale bars $=60 \mu \mathrm{m}$.

resveratrol on nuclear translocation of Gli-1 and the expression of Shh, Ptc-1, Smo and Gli-1 proteins were remarkably suppressed (Fig.3 D, N, E, O, Q, V-Y). Moreover, the suppressing effect of cyclopamine alone was strongest. These results indicated that cyclopamine canceled resveratrol-promoting Gli-1 to translocate into the nuclei from the cytoplasm and enhancing expression of Gli-1,Shh,Ptc-1 and Smo protein. 


\section{Cellular Physiology Cell Physiol Biochem 2018;50:1346-1360 \\ \begin{tabular}{l|l|l} 
DOI: 10.1159/000494593 & O 2018 The Author(s). Published by S. Karger AG, Basel \\
www.karger.com/cpb
\end{tabular} \\ Guo et al.: Resveratrol Activated Sonic Hedgehog Signaling to Enhance Viability of}

NIH3T3 Cells via Sirt1

Taken together, these results suggest that effects of resveratrol-enhancing viability of NIH3T3 cells may be related to the activation of the Shh signaling pathway. In other words, Shh signaling may mediate resveratrol to enhance viability of NIH3T3 cells.

\section{Effect of Sirt1 on Shh Signaling in NIH3T3 Cells}

Here, Sirt1 agonist SRT1720 and antagonist Sirtinol were used to examined whether resveratrol activated Shh signaling to enhance viability of NIHT3 cells in vitro via mediation of Sirt1.

The CCK-8 assay showed that resveratrol $(0.751 \pm 0.05)$, SRT1720 $(0.793 \pm 0.037)$ and Shh protein (an activator of hedgehog signaling, $0.838 \pm 0.418$ ) significantly strengthened the viability of NIH3T3 cells than those in the control group $(0.531 \pm 0.034)$. In contrast, Sirtinol $(0.448 \pm 0.030)$ significantly decreased viability of the NIH3T3 cells than those in the control group (Fig. 4). Further, immunofluorescence double labeling analysis showed that Smo and Gli-1 accumulated in cytoplasm in the control group (Fig. 5E, G, H and Fig. 6D, F ), and Smo translocated to the primary cilia and Gli-1 translocate to the nuclei in the resveratrol (Fig. $5 \mathrm{I}$, K, L and Fig. 6G, I) , SRT1720 (Fig. 5M, O, P and Fig.6 J, L) and Shh (Fig. 5 U, W, X and Fig. 6P, R) groups. On the contrary, Smo and Gli-1 still lied in the cytoplasm in the Sirtinol group (Fig. 5Q, $\mathrm{S}$, T and Fig. 6M, 0). At the same time, Western blotting assay showed that the expressions of Shh, Ptc-1, Smo proteins in cytoplasm and Gli-1 protein in nuclei were significantly increased in the resveratrol, SRT1720 and Shh groups, and significantly decreased in the Sirtinol group than those in the control group (Fig. 6S-W).

These results indicated that Sirt1 could modulate activity of Shh signaling to enhance viability of NIH3T3 cells. In other words, it may be mediated by Sirt1 that resveratrol activated Shh signaling to enhance viability of NIHT3 cells in vitro.

\section{Discussion}

The results of the present study demonstrated that resveratrol at low concentration enhances the viability of NIH3T3 cells, and the most effective concentration of resveratrol is $1 \mu \mathrm{mol} / \mathrm{L}$, and inhibits viability of cells at high concentration. Moreover, NIH3T3 cells have a primary cilium, resveratrol promoted Smo to translocate into the primary cilia and Gli-1 to transferred to the nuclei from the cytoplasm, and enhanced significantly expression of Gli-1 protein in nuclei, Shh, Ptc-1 and Smo protein in cytoplasm. At the same time, Luciferase activity of Gli-1 significantly increased in different concentration resveratrol groups, and the highest was $1 \mu \mathrm{mol} / \mathrm{L}$ resveratrol group which rose up to 8- to 9-fold. Conversely, cyclopamine, a Smo receptor inhibitor, abolished the above effects of resveratrol. In addition, SRT1720, a Sirt1 agonist, and Shh protein, an activator of hedgehog signaling, produced effects similar to resveratrol. Sirtinol, a Sirt1 inhibitor, produced effects similar to cyclopamine. Taken together, these findings provide evidence that Sirt1 may mediate effects of resveratrol-activating the Shh signaling to enhance viability of NIH3T3 cells, and Sirt1 may be a regulator for upstream of the Shh signaling pathway.

Sakata and Dong et al. reported that 1, 1.56 and $5 \mu \mathrm{mol} / \mathrm{L}$ resveratrol strengthened viability and decreased apoptosis of neurons, and 20 and $50 \mu \mathrm{mol} / \mathrm{L}$ resveratrol inhibited viability and reinforced apoptosis of neurons $[43,44]$. Park and Leong et al. reported that 20 and $50 \mu \mathrm{mol} / \mathrm{L}, 30-120 \mu \mathrm{mol} / \mathrm{L}$, respectively, resveratrol inhibited proliferation of neural progenitor cells and embryonic cardiomyoblasts $[45,46]$. Sugino' s study showed that 10 and $20 \mu \mathrm{mol} / \mathrm{L}$ resveratrol strengthened nerve growth factor-induced neurite outgrowth in PC12 cells [47].Ren and Tang et al. reported that $5 \mu \mathrm{mol} / \mathrm{L}$ resveratrol increased proliferation of neural stem cells and promoted synaptogenesis and neurite outgrowth of neurons after OGD/R injury [20,21]. However, Bora-Tatar and Manczak et al. reported that $5 \mu \mathrm{mol} / \mathrm{L}$ resveratrol didn't restore neurite outgrowth defects in deficient PC12 cells or enhance neurite outgrowth in N2a cells $[48,49]$. Our present study showed that resveratrol at low concentration enhanced the viability of NIH3T3 cells and reduced viability of cells 


\section{Cellular Physiology Cell Physiol Biochem 2018;50:1346-1360

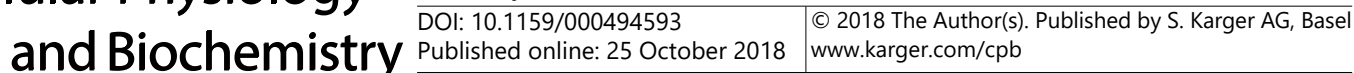 \\ Guo et al.: Resveratrol Activated Sonic Hedgehog Signaling to Enhance Viability of}

NIH3T3 Cells via Sirt1

at high concentration. Therefore, these studies indicate that physiological, pharmacological, toxicological effects of resveratrol depends on many factors, such as the type, physiological or pathological state of cells, tissues or organs, and the concentration and source of resveratrol, and so on. It needs more extensive research.

Fibroblasts are important for the regulation and maintenance of tissue homeostasis, synthesizing and remodeling the extracellular matrix (ECM) consisting predominantly of fibronectin and type I collagen, facilitating maturation of epithelial cells, promoting contraction of granulation tissue during wound healing, and formation of fibrotic scar in the CNS injury [5-7]. In the CNS, fibrogenic cells are restricted to vascular and meningeal niches. Invading meningeal fibroblast-derived cells have been proposed to actively proliferate, deposit excessive ECM proteins, contribute to the generation of connective tissue after brain trauma and form the fibrotic scar,which is believed to represent an absolute barrier for regenerating motor axons $[2,50,51]$ Therefore, it is important to investigate mechanism of fibroblasts for activation, proliferation, differentiation, migration in physiological or pathological state. Shh was reported to promote fibroblast migration and induce vascular adventitial fibroblasts phenotypic modulation, proliferation and migration [52, 53]. In vitro, combined stimulation with Shh and platelet-derived growth factor (PDGF)-BB strongly induced proliferation and migration of human adventitial fibroblasts, and inhibition of Smo selectively prevented fibroblast proliferation. In vivo, Smo-inhibition significantly prevented the proliferation of adventitial fibroblasts and neointima formation following wire-induced injury [54]. In gingival fibroblasts, Shh can mediate cyclosporine-A-altered gingival matrix homeostasis [55]. Moreover, Shh promoted normal rat kidney fibroblast proliferation in vitro, overexpression of Shh promoted fibroblast expansion and aggravated kidney fibrotic lesions after ischemia/reperfusion injury in vivo. Correspondingly, blockade of Shh signaling by cyclopamine inhibited fibroblast proliferation, reduced myofibroblast accumulation, and attenuated renal fibrosis [56]. In addition, Shh-JNK-Gli1 pathway positively regulates high glucose-induced damage on fibroblasts [57]. Here, our study also showed that blockade of Shh signaling by cyclopamine reduced viability of NIH3T3 cells. Therefore, these studies suggest that the Shh signaling can mediate survival, differentiation, proliferation and migration of fibroblasts.

Resveratrol has extensive physiological and pharmacological activities. It can inhibit the proliferation of pathological scar fibroblasts via downregulating the expression of mammalian target of rapamycin (mTOR) /70S6K signaling pathway or TGF- $\beta 1$, Smad-2, 3,4 , and upregulating expression of Smad $7[58,59]$. It can also inhibited proliferation of hypertrophic scar-derived fibroblasts and adventitial fibroblast in vitro and led to a more organized and thinner collagen fibre in the mouse model of wound healing via up-regulating expression of Sirt1[60-62]. Here, we showed that resveratrol could enhance viability of NIH3T3 cells via activating the Shh signaling pathway. These studies suggest that resveratrolinhibiting or -inhancing proliferation of fibroblasts may be mediated by various signaling pathways.

Resveratrol is an activator of Sirt1[33-38]. Whether does resveratrol activate the Shh signaling via Sirt1? In ODG/R injury neurons, Sirt1 antagonist Sirtinol was reported to inhibit the expression of Shh, Ptc-1, Smo, and Gli-1 proteins [21]. On the contrary, in normal and oncogenic neural development, a BCL6/BCOR/SIRT1 complex suppressed the Shh signaling [40]. In neural progenitor cells, Notch signaling was reported to regulate trafficking of the Shh receptor Patched 1 and downstream effector Smoothened to primary cilia [63]. However, Sirt1 could inhibit or activate Notch-mediated transcription. For example, Sirt1 interacted directly with LSD1 and regulated Notch target gene expression [64] . In adult neural stem cells, Sirt1 is a key metabolic sensor for regulating adult hippocampal neurogenesis, partly through its suppression of Notch signaling [65]. In Ewing sarcoma, Sirt1 inhibitors restored abrogation of Notch signaling and caused tumor-growth arrest [66]. Moreover, Sirt1 could repress Notch1 signaling to antagonize fibrosis after chronic renal injury [67] and alleviate sepsis [68]. On the contrary, Sirt1 also positively regulated the Notch pathway in Drosophila, and this might be context-dependent [69]. Here, we observed that Sirt1 


\section{Cellular Physiology Cell Physiol Biochem 2018;50:1346-1360

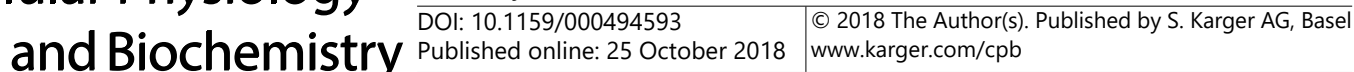 \\ Guo et al.: Resveratrol Activated Sonic Hedgehog Signaling to Enhance Viability of}

NIH3T3 Cells via Sirt1

agonist SRT1720 enhanced viability of NIH3T3 cells and activated the Shh signaling, and Sirt1 antagonist Sirtinol reduced viability of NIH3T3 cells and inhibited the Shh signaling. Therefore, resveratrol-activating the Shh signaling may be related to Sirt1, and Sirt1 may be a regulator for upstream of the Shh signaling pathway, which effects of Sirt1 on the Shh signaling for activation or inhibition may depend on physiological or pathological state of cells, tissues or organs.

\section{Conclusion}

In conclusion, fibroblasts play an important role in formation of fibrotic scar after cerebral injury and it has clinical therapeutic utility to illuminate mechanism of fibroblasts for activation, proliferation, differentiation, migration in physiological or pathological state. Our present study in vitro for the first time showed that resveratrol enhanced viability of NIH3T3 cells, activated the Shh signaling via Sirt1, and Sirt1 may be a regulator for upstream of the Shh signaling pathway. However, after brain or spinal cord injury such as stroke, trauma, infection and degeneration, it is unclear whether resveratrol has same above effects on vascular and meningeal fibroblasts in the CNS. Therefore, in the future, more studies are needed to evaluate the functions of fibrotic scar in the CNS and effects and mechanism of resveratrol and fibroblasts during formation of fibrotic scar after brain or spinal cord injury.

\section{Acknowledgements}

This work was supported by grants from the National Nature Science Foundation of China (grant no. 81671309) and the National Key Clinical Specialties Construction Program of China for Neurology (The First Affiliated Hospital of Chongqing Medical University No [2014].27).

\section{Disclosure Statement}

The authors declare that they have no competing interests.

\section{References}

1 Fitch MT, Silver J: CNS injury, glial scars, and inflammation: Inhibitory extracellular matrices and regeneration failure. Exp Neurol 2008;209:294-301.

-2 Kawano H, Kimura-Kuroda J, Komuta Y, Yoshioka N, Li HP, Kawamura K, Li Y, Raisman G: Role of the lesion scar in the response to damage and repair of the central nervous system.Cell Tissue Res 2012;349:169180.

3 Adams KL, Gallo V: The diversity and disparity of the glial scar.Nat Neurosci 2018;21:9-15.

-4 Cregg JM, DePaul MA, Filous AR, Lang BT, Tran A, Silver J: Functional regeneration beyond the glial scar.Exp Neurol 2014;253:197-207.

-5 Soderblom C, Luo X, Blumenthal E, Bray E, Lyapichev K, Ramos J, Krishnan V, Lai-Hsu C, Park KK, Tsoulfas P, Lee JK: Perivascular fibroblasts form the fibrotic scar after contusive spinal cord injury.J Neurosci 2013;33:13882-13887.

6 Fernández-Klett F, Priller J: The fibrotic scar in neurological disorders.Brain Pathol 2014;24:404-413.

7 Dias DO, Göritz C: Fibrotic scarring following lesions to the central nervous system.Matrix Biol 2018;6869:561-570.

8 Walle T: Bioavailability of resveratrol. Ann N Y Acad Sci 2011;1215:9-15.

-9 Diaz-Gerevini GT, Repossi G, Dain A, Tarres MC, Das UN, Eynard AR: Beneficial action of resveratrol: How and why. Nutrition 2016;32:174-178. 


\section{Cellular Physiology Cell Physiol Biochem 2018;50:1346-1360 and Biochemistry \begin{tabular}{l|l} 
DOI: 10.1159/000494593 & $\begin{array}{l}\text { O } 2018 \text { The Author(s). Published by S. Karger AG, Basel } \\
\text { wwww.karger.com/cpb }\end{array}$
\end{tabular}

Guo et al.: Resveratrol Activated Sonic Hedgehog Signaling to Enhance Viability of

NIH3T3 Cells via Sirt1

10 Varoni EM, Lo FAF, Sharifi-Rad J, Iriti M: Anticancer Molecular Mechanisms of Resveratrol. Front Nutr 2016;3:8.

11 Lin HY, Tang HY, Davis FB, Davis PJ: Resveratrol and apoptosis. Ann N Y Acad Sci 2011;1215:79-88.

12 Gurusinghe S, Cox AG, Rahman R, Chan ST, Muljadi R, Singh H, Leaw B, Mockler JC, Marshall SA, Murthi P, Lim R, Wallace EM: Resveratrol mitigates trophoblast and endothelial dysfunction partly via activation of nuclear factor erythroid 2-related factor-2. Placenta 2017;60:74-85.

13 Ahmed T, Javed S, Javed S, Tariq A, Šamec D, Tejada S, Nabavi SF, Braidy N, Nabavi SM: Resveratrol and Alzheimer's Disease: Mechanistic Insights. Mol Neurobiol 2017;54:2622-2635.

14 Bastianetto S, Ménard C, Quirion R: Neuroprotective action of resveratrol. Biochim Biophys Acta 2015;1852:1195-1201.

15 Singh N, Agrawal M, Doré S: Neuroprotective properties and mechanisms of resveratrol in in vitro and in vivo experimental cerebral stroke models. ACS Chem Neurosci 2013;4:1151-1162.

16 Li F, Gong Q, Dong H, Shi J: Resveratrol, a neuroprotective supplement for Alzheimer's disease. Curr Pharm Des 2012;18:27-33.

17 Jin F, Wu Q Lu YF, Gong QH, Shi JS: Neuroprotective effect of resveratrol on 6-OHDA-induced Parkinson's disease in rats. Eur J Pharmacol 2008;600:78-82.

18 Sinha K, Chaudhary G, Gupta YK: Protective effect of resveratrol against oxidative stress in middle cerebral artery occlusion model of stroke in rats. Life Sci 2002;71:655-665.

19 Yu P, Wang L, Tang F, Zeng L, Zhou L, Song X, Jia W, Chen J, Yang Q: Resveratrol Pretreatment Decreases Ischemic Injury and Improves Neurological Function Via Sonic Hedgehog Signaling After Stroke in Rats. Mol Neurobiol 2017;54:212-226.

20 Ren J, Fan C, Chen N, Huang J, Yang Q: Resveratrol pretreatment attenuates cerebral ischemic injury by upregulating expression of transcription factor Nrf2 and HO-1 in rats. Neurochem Res 2011;36:2352-2362.

-21 Tang F, Guo S, Liao H, Yu P, Wang L, Song X, Chen J, Yang Q: Resveratrol Enhances Neurite Outgrowth and Synaptogenesis Via Sonic Hedgehog Signaling Following Oxygen-Glucose Deprivation/Reoxygenation Injury. Cell Physiol Biochem 2017;43:852-869.

22 Cheng W, Yu P, Wang L, Shen C, Song X, Chen J, Tang F, Yang Q: Sonic hedgehog signaling mediates resveratrol to increase proliferation of neural stem cells after oxygen-glucose deprivation/reoxygenation injury in vitro. Cell Physiol Biochem 2015;35:2019-2032.

-23 Shen C, Cheng W, Yu P, Wang L, Zhou L, Zeng L, Yang Q: Resveratrol pretreatment attenuates injury and promotes proliferation of neural stem cells following oxygen-glucose deprivation/reoxygenation by upregulating the expression of Nrf2, HO-1 and NQO1 in vitro. Mol Med Rep 2016;14:3646-3654.

24 Mehta M, Branford OA, Rolfe KJ: The evidence for natural therapeutics as potential anti-scarring agents in burn-related scarring. Burns Trauma $2016 ; 4: 15$.

25 Ikeda K, Torigoe T, Matsumoto Y, Fujita T, Sato N, Yotsuyanagi T: Resveratrol inhibits fibrogenesis and induces apoptosis in keloid fibroblasts.Wound Repair Regen 2013;21:616-623.

26 Choy SW, Cheng SH: Hedgehog signaling. Vitam Horm 2012;88:1-23.

-27 Rohatgi R, Milenkovic L, Scott MP: Patched1 regulates hedgehog signaling at the primary cilium. Science 2007;317:372-376.

-28 Singla V, Reiter JF: The primary cilium as the cell's antenna: signaling at a sensory organelle. Science 2006;313:629-633.

29 Huang SS1, Cheng H, Tang CM, Nien MW, Huang YS, Lee IH, Yin JH, Kuo TB, Yang CC, Tsai SK, Yang DI: Antioxidative, anti-apoptotic, and pro-angiogenic effects mediate functional improvement by sonic hedgeho g against focal cerebral ischemia in rats. Exp Neurol 2013;247:680-688.

-30 Chechneva OV, Mayrhofer F, Daugherty DJ, Krishnamurty RG, Bannerman P, Pleasure DE, Deng W: A Smoothened receptor agonist is neuroprotective and promotes regeneration after ischemicbrain injury. Cell Death Dis 2014;5:e1481.

-31 Zhang L, Chopp M, Meier DH, Winter S, Wang L, Szalad A, Lu M, Wei M, Cui Y, Zhang ZG: Sonic hedgehog signaling pathway mediates cerebrolysin-improved neurological function after stroke. Stroke 2013;44:1965-1972.

32 Huang JG, Shen CB, Wu WB, Ren JW, Xu L, Liu S, Yang Q: Primary cilia mediate sonic hedgehog signaling to regulate neuronal-like differentiation of bone mesenchymal stem cells for resveratrol induction in vitro. J Neurosci Res 2014;92:587-596. 


\section{Cellular Physiology Cell Physiol Biochem 2018;50:1346-1360 \begin{tabular}{ll|l} 
and Biochemistry Published online: 25 October 2018 & $\begin{array}{l}\text { @ } 2018 \text { The Author(s). Published by S. Karger AG, Basel } \\
\text { www.karger.com/cpb }\end{array}$ \\
\hline
\end{tabular}}

Guo et al.: Resveratrol Activated Sonic Hedgehog Signaling to Enhance Viability of NIH3T3 Cells via Sirt1

-33 Sacconnay L, Carrupt PA, Nurisso A: Human sirtuins: Structures and flexibility. J Struct Biol 2016;196:534542.

-34 Correia M, Perestrelo T, Rodrigues AS, Ribeiro MF, Pereira SL, Sousa MI, Ramalho-Santos J: Sirtuins in metabolism, stemness and differentiation. Biochim Biophys Acta 2017;1861:3444-3455.

-35 Tang BL: Sirtuins as modifiers of Parkinson's disease pathology. J Neurosci Res 2017;95:930-942.

-36 Hou X, Rooklin D, Fang H, Zhang Y: Resveratrol serves as a protein-substrate interaction stabilizer in human SIRT1 activation. Sci Rep 2016;6:38186.

-37 Price NL, Gomes AP, Ling AJ, Duarte FV, Martin-Montalvo A, North BJ, Agarwal B, Ye L, Ramadori G, Teodoro JS, Hubbard BP, Varela AT, Davis JG, Varamini B, Hafner A, Moaddel R, Rolo AP, Coppari R, Palmeira CM, de Cabo R et al.: SIRT1 is required for AMPK activation and the beneficial effects of resveratrol on mitochondrial function. Cell Metab 2012;15:675-690.

-38 Buler M, Andersson U, Hakkola J: Who watches the watchmen? Regulation of the expression and activity of sirtuins. FASEB J 2016;30:3942-3960.

39 Bai XZ, Liu JQ Yang LL, Fan L, He T, Su LL, Shi JH, Tang CW, Zheng Z, Hu DH: Identification of sirtuin 1 as a promising therapeutic target for hypertrophic scars.Br J Pharmacol 2016;173:1589-1601.

40 Tiberi L, Bonnefont J, van den Ameele J, Le BSD, Herpoel A, Bilheu A, Baron BW, Vanderhaeghen P: A BCL6/BCOR/SIRT1 complex triggers neurogenesis and suppresses medulloblastoma by repressing Sonic Hedgehog signaling.Cancer Cell 2014;26:797-812.

41 Lin SL, Kisseleva T, Brenner DA, Duffield JS: Pericytes and perivascular fibroblasts are the primary source of collagen producing cells in obstructive fibrosis of the kidney. Am J Pathol 2008;173:1617-1627.

42 Scholten D, Reichart D, Paik YH, Lindert J, Bhattacharya J, Glass CK, Brenner DA, Kisseleva T: Migration of fibrocytes in fibrogenic liver injury. Am J Pathol 2011;179:189-198.

43 Sakata Y, Zhuang H, Kwansa H, Koehler RC, Doré S: Resveratrol protects against experimental stroke: putative neuroprotective role of heme oxygenase 1. Exp Neurol 2010;224:325-329.

-44 Dong W, Li N, Gao D, Zhen H, Zhang X, Li F: Resveratrol attenuates ischemic brain damage in the delayed phase after stroke and induces messenger RNA and protein express for angiogenic factors. J Vasc Surg 2008;48:709-714.

45 Park HR, Kong KH, Yu BP, Mattson MP, Lee J: Resveratrol inhibits the proliferation of neural progenitor cells and hippocampal neurogenesis. J Biol Chem 2012;287:42588-42600.

46 Leong CW, Wong CH, Lao SC, Leong EC, Lao IF, Law PT, Fung KP, Tsang KS, Waye MM, Tsui SK, Wang YT, Lee SM: Effect of resveratrol on proliferation and differentiation of embryonic cardiomyoblasts. Biochem Biophys Res Commun 2007;360:173-180.

47 Sugino T, Maruyama M, Tanno M, Kuno A, Houkin K, Horio Y: Protein deacetylase SIRT1 in the cytoplasm promotes nerve growth factor-induced neurite outgrowth in PC12 cells. FEBS Lett 2010;584:2821-2826.

$\$ 48$ Bora-Tatar G, Erdem-Yurter H: Investigations of curcumin and resveratrol on neurite outgrowth: perspectives on spinal muscular atrophy. Biomed Res Int 2014;2014:709108.

-49 Manczak M, Mao P, Calkins MJ, Cornea A, Reddy AP, Murphy MP, Szeto HH,Park B, Reddy PH: Mitochondriatargeted antioxidants protect against amyloid-beta toxicity in Alzheimer's disease neurons. J Alzheimers Dis 2010;20 Suppl 2:S609-631.

50 Yoshioka N, Hisanaga S, Kawano H: Suppression of fibrotic scar formation promotes axonal regeneration without disturbing blood-brain barrier repair and withdrawal of leukocytes after traumatic brain injury. J Comp Neurol 2010;518:3867-3881.

51 Li HP, Komuta Y, Kimura-Kuroda J, van Kuppevelt TH, Kawano H: Roles of chondroitin sulfate and dermatan sulfate in the formation of a lesion scar and axonal regeneration after traumatic injury of the mouse brain. J Neurotrauma 2013;30:413-425.

52 Li FH, Xin SJ, Zhang SY, Cui ZS, Gao J, Zhang J, Duan ZQ: The sonic hedgehog induce vascular adventitial fibroblasts phenotypic modulation, proliferation and migration.Zhonghua Yi Xue Za Zhi 2009;89:30793082.

53 Polizio AH, Chinchilla P, Chen X, Kim S, Manning DR, Riobo NA: Heterotrimeric Gi proteins link Hedgehog signaling to activation of Rho small GTPases to promote fibroblast migration.J Biol Chem 2011;286:1958919596.

54 Dutzmann J, Koch A, Weisheit S, Sonnenschein K, Korte L, Haertlé M, Thum T, Bauersachs J, Sedding DG, Daniel JM: Sonic hedgehog-dependent activation of adventitial fibroblasts promotes neointima formation. Cardiovasc Res 2017;113:1653-1663. 


\section{Cellular Physiology Cell Physiol Biochem 2018;50:1346-1360 \begin{tabular}{ll|l} 
DOI: 10.1159/000494593 & $\begin{array}{l}\text { O 2018 The Author(s). Published by S. Karger AG, Basel } \\
\text { www.karger.com/cpb }\end{array}$ \\
\hline
\end{tabular}}

Guo et al.: Resveratrol Activated Sonic Hedgehog Signaling to Enhance Viability of

NIH3T3 Cells via Sirt1

55 Chung Y, Fu E, Chin YT, Tu HP, Chiu HC, Shen EC, Chiang CY: Role of Shh and TGF in cyclosporine-enhanced expression of collagen and a -SMA by gingival fibroblast.J Clin Periodontol 2015;42:29-36.

56 Zhou D, Li Y, Zhou L, Tan RJ, Xiao L, Liang M, Hou FF, Liu Y: Sonic hedgehog is a novel tubule-derived growth factor for interstitial fibroblasts after kidney injury.J Am Soc Nephrol 2014;25:2187-2200.

-57 Song N, Wang H, Gu T, Qi J, Yang J, Qiu Y, Chen Q, Zou Y, Chen Y, Hu Q Ma X, Zhao T, Feng Z: Sonic hedgehogc-Jun N-terminal kinase-zinc finger protein Gli1 signaling protects against high glucose concentrationinduced reactive oxygen species generation in human fibroblasts.Exp Ther Med 2018;15:5084-5090.

-58 Tang ZM, Zhai XX, Ding JC: Expression of mTOR/70S6K signaling pathway in pathological scar fibroblasts and the effects of resveratrol intervention. Mol Med Rep 2017;15:2546-2550.

-59 Zhai XX, Ding JC, Tang ZM: Resveratrol Inhibits Proliferation and Induces Apoptosis of Pathological Scar Fibroblasts Through the Mechanism Involving TGF- $\beta 1 /$ Smads Signaling Pathway.Cell Biochem Biophys 2015;71:1267-1272.

60 Bai XZ, Liu JQ Yang LL, Fan L, He T, Su LL, Shi JH, Tang CW, Zheng Z, Hu DH: Identification of sirtuin 1 as a promising therapeutic target for hypertrophic scars. Br J Pharmacol 2016;173:1589-1601.

61 Zeng G, Zhong F, Li J, Luo S, Zhang P: Resveratrol-mediated reduction of collagen by inhibiting proliferation and producing apoptosis in human hypertrophic scar fibroblasts.Biosci Biotechnol Biochem 2013;77:23892396.

62 Ling L, Gu S, Cheng Y: Resveratrol inhibits adventitial fibroblast proliferation and induces cell apoptosis through the SIRT1 pathway.Mol Med Rep 2017;15:567-572.

63 Kong JH, Yang L, Dessaud E, Chuang K, Moore DM, Rohatgi R, Briscoe J, Novitch BG: Notch activity modulates the responsiveness of neural progenitors to sonic hedgehog signaling.Dev Cell 2015;33:373387.

64 Mulligan P, Yang F, Di Stefano L, Ji JY, Ouyang J, Nishikawa JL, Toiber D, Kulkarni M, Wang Q NajafiShoushtari SH, Mostoslavsky R, Gygi SP, Gill G, Dyson NJ, Näär AM: A SIRT1-LSD1 corepressor complex regulates Notch target gene expression and development. Mol Cell 2011;42:689-699.

65 Ma CY, Yao MJ, Zhai QW, Jiao JW, Yuan XB, Poo MM: SIRT1 suppresses self-renewal of adult hippocampal neural stem cells. Development 2014;141:4697-4709.

66 Ban J, Aryee DN, Fourtouna A, van der Ent W, Kauer M, Niedan S, Machado I, Rodriguez-Galindo C, Tirado OM, Schwentner R, Picci P, Flanagan AM, Berg V, Strauss SJ, Scotlandi K, Lawlor ER, Snaar-Jagalska E, Llombart-Bosch A, Kovar H: Suppression of deacetylase SIRT1 mediates tumor-suppressive Notch response and offers a novel treatment option in metastatic Ewing sarcoma. Cancer Res 2014;74:6578-6588.

67 Kida Y, Zullo JA, Goligorsky MS: Endothelial sirtuin 1 inactivation enhances capillary rarefaction and fibrosis following kidney injury through Notch activation. Biochem Biophys Res Commun 2016;478:10741079.

68 Bai X, He T, Liu Y, Zhang J, Li X, Shi J, Wang K, Han F, Zhang W, Zhang Y, Cai W, Hu D: Acetylation-Dependent Regulation of Notch Signaling in Macrophages by SIRT1 Affects Sepsis Development.Front Immunol 2018;9:762.

69 Horvath M, Mihajlovic Z, Slaninova V, Perez-Gomez R, Moshkin Y, Krejci A: The silent information regulator 1 (Sirt1) is a positive regulator of the Notch pathway in Drosophila. Biochem J 2016;473:4129-4143. 